\title{
Improving Student Career Planning in Industrial Revolution 4.0 Through Career Information Service for Students of SMA Negeri 14 Medan
}

\author{
Edidon Hutasuhut $^{1 *}$, Anggi Nurhasanah Sitorus ${ }^{2}$ \\ ${ }^{1,2)}$ Guidance and Counseling Study Program, Universitas Negeri Medan, Indonesia \\ *edidonhutasuhut@unmed.ac.id
}

\begin{abstract}
This study aims to improve student career planning in the Industrial Revolution Era 4.0 through Career Information Services. This research used counseling guidance action research (PTBK), and the students of class XI at SMA 4 Medan Indonesia as respondents. Data collection techniques using questionnaires, interviews and observations. Data analysis used descriptive by explaining the results of score in first cycle and second cycle. The results of the analysis of Cycle I and Cycle II, based on the results of Cycle I after being given actions obtained by 10 students who increased with the acquisition of $32.25 \%$. In the second cycle there was an increase with a percentage of $90.32 \%$ because 28 students were in the high category. Thus, it can be concluded that student career planning in the industrial revolution era 4.0 can be improved through career information services.
\end{abstract}

Keywords: career information services, career planning, industrial revolution era 4.0

\section{Introduction}

Senior High School (SMA) students in the adolescent category in their development have certain tasks. One of the tasks of developing high school youth is having readiness to face the world of work or career. Havighurst states there are several developmental tasks that must be completed that must be achieved by students for a career or job.

According to Umam Suherman [1] adolescents are said to have problems in their careers when they do not reach career maturity in accordance with the stages and tasks of career development, which is shown in the behavior "first is less able to plan careers well, second is lazy to explore, third is less adequate knowledge about making career decisions, fourth lacking knowledge (information) about the world of work, fifth lacking knowledge about preferred occupational groups, sixth not achieving realism career decisions, and seventh inadequate career orientation so that consequently unable to make career planning and decisions right.

Social changes that occur today include a variety of ways as a result of the development of technology and community needs. This development cannot be ignored anymore considering the rapid development of technology in the current 4.0 industrial revolution which is marked by the participation of IoT and artificial intelligence can even be said to be inseparable from these developments. This is at the core of current progress which is marked by the large amount of work that has been replaced by technology and artificial intelligence as a major role that revolution. 
Facing the rapid development of technology will also have an impact on students who want to continue their education or who directly enter the workforce. This is caused by the work that is usually done by humans now has been replaced by machines or other equipment instead because it is relatively faster and more cost effective. This industrial revolution brings opportunities as well as challenges, especially for students. Such conditions increasingly encourage the importance of making appropriate career planning in the era of the industrial revolution 4.0 with the hope that students will not be wrong in making career decisions in the future. Thus, in helping to improve student career planning it can be started by providing a variety of clear career information so that students can sort out and choose the types of work available so that students can plan a career according to their characteristics.

The existence of fierce competition to enter the workforce as well as to enter a leading university makes unemployment increase which comes from high school graduates increasing. According to information from the Indonesian Central Statistics Agency (CSA) as of February 2019, the total workforce of 136.18 million people and open unemployment rate based on the level of education type, the percentage of unemployed graduates of Vocational High Schools (VHS) was 8.63\%, followed by Senior High School (SHS) of 6.78\%.

The Central Statistics Agency recorded an increase in unemployment in North Sumatra in 2019. The number increased by around 11,000 people from 403,000 to 414,000 compared to February 2018. The Open Unemployment Rate in North Sumatra Province in February 2019 was at $5.56 \%$ from labor force participation. This percentage decreased compared to February 2018 which was 5.59\%. The increase in unemployment in North Sumatra occurred following a surge in the workforce. The number increased by 224,000 to 7.45 by February 2019. Of the 224,000 new work force, there were 11,000 unemployed.

Career planning is one of the most important aspects in pursuing a career and individual career development. Decision-making skills are goals in planning a career that must be taken by each individual. Related to the above situation, there are several problems at school. Based on interviews with the Guidance Counseling Teacher obtained information that there are still students who do not know the information about themselves both their interests, talents and abilities. There are still many students who have not been able to decide on their career direction. Students also lack knowledge of further education and expertise needed in one area of work, and do not know the types of careers that will develop and are needed in the future. This results in students feeling confused in continuing in which direction they will choose or work where after graduating from high school. Plus there is no career information service implementation by Counseling Teacher (CT).

The above phenomenon shows that important career information is owned by students. . For this reason, after graduating they are able to have work readiness, high school students need to prepare themselves in terms of career planning. Therefore, guidance and counseling services need to be activated again in view of the opportunities and challenges that students will face later and so students can also prepare themselves by making career plans long ago and determine alternative career choices that are appropriate in order to be able to keep up with changes in the era industrial revolution 4.0. One effort that can be given to solve student career problems is by providing career information services to students.

\section{Career Planning}

Herr \& Crammer [1] career describes a person who views his work as a vocation that permeates the entire nature of his thoughts and feelings while coloring the entire lifestyle (life styles) of his life, career is more than just work, career is related to how individuals see himself. Homby states that a career is a job, a profession. Someone will work happily, with 
excitement if what is done is in accordance with his circumstances, according to his abilities, according to his interests [2]. Career can be said as a range of interconnected work activities, in this case a person advancing his life by involving various behaviors, abilities, attitudes, needs, aspirations and ideals as a span of his own life (the span of one's life). Based on this understanding, it can be concluded that a career is an individual development and an important part in one's success in advancing life by involving various potentials and abilities possessed during the life span.

According to Frank Parsons, formulating career planning is a way of assisting students in choosing a career field that suits their potential, so that it can be quite successful in the field of work. Career planning needs to be prepared before students enter directly in the career world. Simamora [2] argues that career planning is a process by which individuals can identify and take steps to achieve career goals. Career planning involves identifying career-related goals and compiling plans to achieve those goals [3]. In the career planning process, individuals will gain knowledge about their potential, which includes skills, interests, knowledge, motivations, and characteristics that are used as a basis for career selection, then proceed to determine the stages to be able to achieve a chosen career.

From this description it can be concluded that career planning is a process in career selection and taking steps to achieve desired career goals in accordance with the potential within oneself. In the career planning process individuals will gain knowledge about selfunderstanding, knowledge of the understanding of the world of work and choose further education and occupations that are in accordance with their talents.

\section{Industrial Revolution Era 4.0}

The term Industrial Revolution 4.0 was put forward by Prof. Schawab [4] an economist from Germany, he explained that the industrial revolution 4.0 had fundamentally changed human life and work. Unlike the previous industrial revolution, the 4th generation industrial revolution has a wider scale, scope and complexity. Advances in new technologies that integrate the physical, digital and biological worlds have affected all disciplines, economics, industry and government.

The discovery of electrical energy and the concept of division of labor to produce large quantities of production in the early 19th century marked the birth of the 2.0 industrial revolution. Electricity encourages scientists to find various other technologies such as lights, telegraph machines, and conveyor belts technology. At its peak, production efficiency was obtained up to $300 \%$.

The rapid development of science and technology in the early 20th century has given birth to information technology and production processes that are controlled automatically. Industrial machinery is no longer controlled by human labor but uses a Programmable Logic Controller (PLC) or a computer-based automation system. As a result, production costs are becoming increasingly cheap. Information technology is also increasingly advanced including camera technology that is integrated with mobile phones and the development of the creative industry in the music world with the discovery of digital music.

The industrial revolution is at its peak today with the birth of digital technology which has a massive impact on human life throughout the world. The latest industrial revolution or fourth generation is driving automation in all activity processes. The increasingly massive internet technology not only connects millions of people around the world but has also become the basis for online trade and transportation transactions. The emergence of online transportation businesses such as Gojek, Uber and Grab shows the integration of human activities with information technology and the economy is increasing. The development of autonomous 
vehicle technology, drones, social media applications, biotechnology and nanotechnology increasingly confirms that the world and human life have fundamentally changed.

Other opinions say that the Industrial Revolution 4.0 is a moment that changes the order of human life including managing human resources [5]. This change certainly greatly influences the demands on Indonesian human resources in order to meet superior competence. Progress in the field of technology and infrastructure alone will not answer the existence of complementary needs for human welfare that should be achieved.

\section{Career Information Services}

According to Prayitno [6] information services namely activities provide understanding to individuals who are interested in various things needed to determine the direction of a desired goal or plan. Information services are provided to equip students with knowledge about data and facts in the field of school education, work and personal-social development, so that they, by learning about their environment, are better able to organize and plan their own lives.

According to Nurihsan [7] information services are services providing information needed by individuals. The purpose of this service is for individuals to have adequate knowledge (information), both about themselves and about their environment, the environment of universities, the community, and learning resources including the internet. Information obtained by individuals is needed so that individuals are easier to make plans and make decisions. According to Mulyadi [8] information services are guidance and counseling services that enable students to receive and understand information that can be used as material for decision making in the interests of students.

\section{Research Method}

This type of research is a Guidance and Counseling action research. The study was conducted at SMA Negeri 14 Medan Indonesia, with the subject of the research being students of class XI Science.4, totaling 31 students. Data collection techniques used questionnaire, observation and interview [9]. This guidance and counseling action research design refers to the Kemmis and Taggart model, which includes two cycles and in each cycle each cycle consists of 4 (four) stages namely compiling an action plan, implementing actions, observing, and reflecting. If the first cycle of action has not been successful, it can be continued to the next cycle until the end of low career planning ability can be further increased.

To calculate the percentage of answers given by respondents, the formula as below:

$$
\mathrm{P}=\mathrm{f} / \mathrm{n} \times 100 \%
$$

The success of this research will be evaluated through the results of a percentage of problem alleviation in short-term research with the following evaluation criteria:

$0 \%-25 \%=$ It didn't work

$26 \%-50 \%=$ Less successful

$51 \%-74 \%=$ Quite successful

$75 \%-100 \%=$ Successful

Research is said to be good if it reaches the category of success in the level of student career planning reaching $75 \%$, but if it has not reached the score expected to be continued to the next cycle (second). 


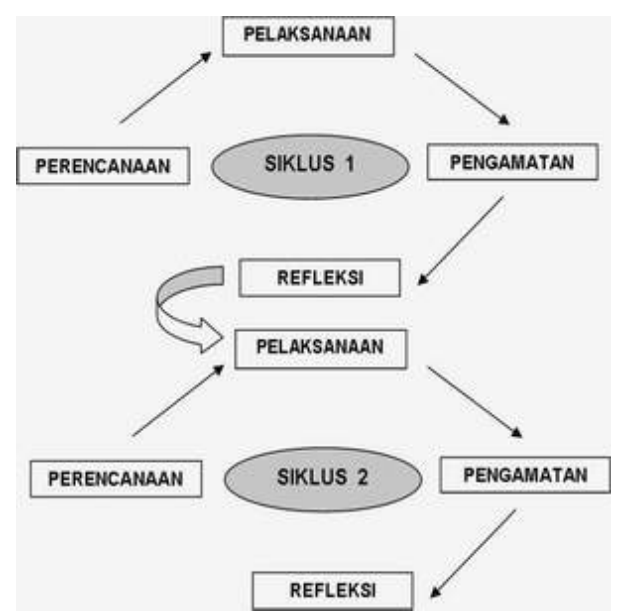

Figure 1. Counseling Guidance Action Research Scheme

\section{Results and Discussion}

\section{Pre Cycle}

General description of career planning for students of class XI Science.4 revealed through the career planning questionnaire obtained data that students who score a low number of 20 students $(64.51 \%)$ and the number of moderate scores of 11 students $(35.48 \%)$, this shows that the level of career planning for students in the low category, thus based on these figures it can be seen that the achievement of career planning for career students is not optimal.

\section{Career Planning Cycle I}

In research the guidance and counseling action by providing career information services is carried out through several stages including:

1) Planning Phase. The researcher conducted several activities namely compiling a service implementation plan (RPL). In addition, researchers also prepare student worksheets, observation guidelines, instrument evaluation results and student attendance lists. In addition, BK teachers provide an allocation of time and place for action.

2) Implementation Stage. Implementation of service activities at the first meeting. Researchers briefly explained the material to self-understanding then gave the task to fill in the worksheets. Students discussing with their friends assisted by researchers about career information material by expressing understanding and problems in accordance with the material that has been delivered. Implementation of service activities at the second meeting, Researchers explain the material in a way briefly about recognizing the understanding of the world of work in which the era of the industrial revolution 4.0, researchers condition the class to conduct discussions with friends by expressing understanding and problems in accordance with the material that has been delivered.

Stage of observation. From the results of observations of the first cycle, the results of observations on action I on the aspect of readiness were still found by some students who were not ready to receive services. In the aspect of student activity, students choose silence when given the opportunity to ask questions. In the aspect of attention, students' enthusiasm when 
services are also shown when students pay attention to services, but still found a student is using a gadget. To find out the magnitude of student career planning, at the end of the first cycle the questionnaire was given to students' career planning and the results were an increase of $32.25 \%$ with the number of 10 students in the high category. However, this condition has not yet reached the set target of $75 \%$. In addition, the observation results when the teacher conveys information there are still weaknesses in the emphasis of the material presented and some students who have not been serious. To determine the next cycle the researcher will look at the results of observations on the activities the teacher conveys and students when participating in activities carrying out information services.

\section{Career planning cycle II}

1) Planning phase The first meeting of the second cycle on Saturday, September 14, 2019, with plans to make a service implementation plan (RPL). Cycle II is carried out through two meetings, the first meeting discusses job information in accordance with talents and interests and the second meeting contains material about the meaning and importance of career planning. What are the steps in career planning.

2) Implementation Phase Implementation of service activities at the first meeting, the researcher examines the level of readiness of students, Conducts questions and answers about the material to be delivered. Each student discusses with his friend about career information based on the material that has been delivered. The implementation of service activities at the second meeting, researchers examined the level of readiness of students, Doing questions and answers, each student discussing with his friends about career information based on the tasks given, then conduct discussions together. The reflection from the counselor regarding the material starts from cycle I and cycle II. Draw conclusions together on the career information service activities.

3) Observation Stage. The result of observation is that the first cycle of action II has seen little difference or improvement from the actions taken in cycle I. Because students have started to be enthusiastic and serious in following the implementation of the second cycle. Students also look active, as evidenced by the presence of several students who ask questions. Students also seemed very concerned about the researcher in explaining, it was proven the class was not noisy and the students did not talk alone with their friends. When working on worksheets students also look serious and have serious discussions. After being given action in this second cycle, the percentage of students' career planning questionnaire results reached $90.32 \%$ with 28 students in the high category.

From the results of the analysis of the research data above, it is known that the provision of actions taken gives a significant change to students' career planning. This is indicated by the questionnaire score of student career planning that is increasing from pretest to cycle II. If at the pretest the student career planning questionnaire score was $0 \%$, then after the first cycle it increased to $32.25 \%$ and increased again to $90.32 \%$ after the second cycle. The results of student responses indicate that most students stated that they increasingly knew and understood about career information after being given this action. This shows that this research was successful in improving student career planning. This success can be seen in the changes that occurred before, during and after this action was given. Changes that occur can be seen: 


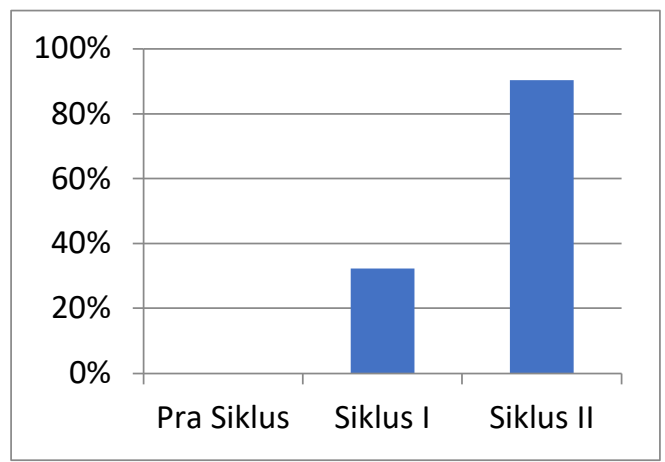

Figure 1. Cycles of Action research

Based on the comparison between before, during and after the administration of the above actions, it can be concluded that there is a significant increase in student career planning between before, during and after the provision of career information services. Thus the action hypothesis that reads "career planning students in the industrial revolution era 4.0 can be increased through the provision of career information services" can be accepted.

\section{Type of Employment which is the most reduced}

1) Cashier

Working as a cashier might have been very popular 15-20 years ago. Many outlets or stores that require the services of a cashier to manage sales in the store. Over time, job openings as cashiers began to decrease. This is due to changes in people's lifestyles that used to shop in stores have now shifted to online shopping. Not to mention the emergence of the issue regarding the presence of an automatic cash register. Where buyers can make their own payments without the help of a cashier.

2) Toll Counter Officers

Some highways today are very sophisticated. If there used to be employees assigned to collect toll money, several toll roads are now using machine technology. Simply by attaching electronic money, you as a toll road user can access the toll road freely.

3) Receptionist

The receptionist works as a telephone receiver and guest registrar present at a place. Apparently, this position is not needed anymore due to the presence of a virtual telephone machine that can answer callers' calls automatically. This virtual telephone technology has been widely applied in developed countries, such as Japan.

4) Bank Tellers

Bank tellers work to receive deposits and cash payments from a customer. However, this work seems to be lost a few years later because of the presence of an ATM virtual machine that functions the same as the bank's teller. According to research, $85 \%$ of work that is usually done by bank tellers can now be done through an ATM machine.

5) Travel Agency

Although the profession as a travel agent is increasingly booming, the popularity of this profession is believed to be lost over the next few decades. Because today's society can already order tickets online. That way, people do not need to visit the services of a travel agent again every time they want to order a ticket. 
6) Introduction to Letters

The profession as an introduction to a letter might have been needed 20 years ago. However, this profession is increasingly receding because the process of sending letters can be done through digital media, for example e-mail. In fact, sending letters via email is increasingly popular because the process of delivering information is faster, no need to wait for days.

7) Photo Printer

A few years ago, the photo printing business was very promising given the increasing public demand for photo washing services. Over time, the demand for photo printing has diminished because people have been able to print their own photos at home. Not to mention the presence of the Instamini camera as an automatic photo printing machine.

8) Cassette Seller

Watching movies becomes the most fun activity to fill vacation time. If in the past you often found a cassette or CD seller in the middle of the road, now no longer. The cassette seller profession has become extinct because the public is increasingly able to access films he likes for free via the internet.

9) Census Workers

If in the past the community's data collection in an area was done directly or plunged into the field, now it is no longer. Now many companies have chosen to use population data recording software. The work system software is also more accurate, efficient, and fast.

The revolution must be addressed wisely. The world of technology will continue to evolve, both in the positive and negative directions. The technological revolution has also proven capable of removing humans from their jobs. Address technology development wisely. Take advantage of this technology to find more decent jobs for the future.

\section{As a result of the 4.0 Industrial Revolution on employment}

The emergence of technology in human life can have an impact starting from the work that benefits are individual or group / industrial. In particular, this group / industry nature is closely related to aspects in the world of apes. Technological innovations that occurred in the industrial revolution 4.0 not only have an impact on a variety of jobs that are conventional with the machine, but there are also changes in work culture in various industrial sectors.

Work culture changes that can occur and even some of us can feel include (1) analytical work, (2) work that requires mathematical abilities, (3) work that is a digital technology, (4) mobilization at work, (5) the importance of collaboration, communication and critical thinking.

Analytical work. Innovations in the era of the industrial revolution such as the internet of things or data processing make analytical skills very necessary. In the future this analytical work will be very much needed in various fields, because the work of this analysis is very closely related to the development of technology itself. some data analysis activities such as analyzing the identification of various trends that occur, describing changes, to illustrate a variety of ideas from existing data.

Jobs that require mathematical abilities. Mathematical ability or skills related to numbers are expected to be needed in the future. Mathematical ability or skills associated with this number is very broad field of work, such as robotics engineers, architects, fashion designers, programming experts, forensics experts, photographers and many more. For example in the social sphere this will develop. As the need for quantitative data and special information to retrieve important decisions. jobs that are digital technology. With technological innovation 
along, it underpins aspects of everyday life, including in the world of work. Every workforce is required to be able to live side by side with technology, therefore every worker is required to have good digital literacy skills, this aims to increase maximum productivity.

Mobilization in this work will be very easy to find and feel. Where workers will experience a move from one company to another or from one place to another, this aims to provide an opportunity to develop themselves again.

However, every society undergoing this industrial revolution is not prepared, because they must be confronted with a new system or work. Although this happens quickly, it will encourage every worker to participate and contribute to the abilities of the workers the importance of collaboration, communication and critical thinking. Jobs that require interaction with people, jobs that deal directly with machines, work that is social in nature. All three capabilities must be possessed by workers. For example, a technician not only has the ability to deal with machines, the worker must also be able to collaborate with other colleagues, both to create and to get ideas together. The result of this research relevance with another studies, like Dillard, Wulan Ayodya [10], Adiputri and Dwikurnaningsih [11], Anisa, Laelatul [12].

\section{Career Information to avoid mistakes in choosing a career in the future}

1) Listen to Other People

That You Have to Do One Thing Or on the other hand, that you shouldn't do something. Many people think they have the right to determine what career you should choose, such as your parents, friends, or spouse. In fact, this is wrong. No one else has the right to do this but yourself. The career you choose may have little impact on the lives of the people in your life. However, it is you who must bear the consequences the most. Therefore, listening to the advice and advice of others is wise. But, make sure that you go through the career you want so you enjoy it.

2) Following Other People's Steps

You may be haunted by the expectations of parents to choose the same career that they live. You may feel this is your duty as a child, because you owe a lot to your parents. Indeed, it is hard to ignore the pressure from the family. However, living a career just to please others is not a wise foundation. What is true for your parents is not necessarily good for you. In the long run, people who care about you actually only want you to be happy. So, make sure you choose a career that suits your heart and can give you happiness.

3) Do Not Research First send the CV to the email

Never choose a career before spending time studying it. Before you dive into the professional world, be sure to understand the job descriptions of the profession that interests you. Understand the obligations, educational experience, and income related to that career. Chat with those who have gone through this career. Those who work in your desired field can give you a narrative based on their experience of the reality of undergoing that career.

4) Only concerned about financial money

Getting a large salary and meeting your needs and desires is very important. However, the actual salary amount is not related to the satisfaction you can get from work. If you get paid tens of millions of rupiah each month but you hate your job, then you will not be able to enjoy the results of your hard work to perfection. Therefore, balance between earning enough to meet your needs and work that can make you enjoy it. Don't ignore yourself. Your personality type, interests, values, and talents will influence which type of profession is more suitable for you than others. This is an intrinsic character. That is, you 
cannot change it. Therefore, if you do not consider these things in choosing a career, maybe later you will regret it because it does not suit you.

5) Ignoring the Future

Even though you should not choose to work based only on trends or what people say about the "best profession," you should still consider the prospects of future work. You really don't have a magic crystal ball that can tell you whether a profession will develop or become stable in the future. However, you can still predict by reading various sources. You still have to consider whether the future of your chosen career is promising.

Avoiding mistakes in choosing a career means increasing your chance to enjoy the career you are building.

\section{Conclusion}

Based on the results of data analysis and discussion, it is known that the percentage of career planning scores of students from each cycle increased significantly, when given career information services in the first cycle was $32.25 \%$ and in the second cycle increased significantly $90.32 \%$. The career information service process is going well and has achieved success that is set at $75 \%$. Thus, it can be concluded that student career planning in the industrial revolution era 4.0 can be improved by providing career information services.

Based on the above conclusions, then as a suggestion the authors can put forward in this study are:

1) For schools to better facilitate information service activities in an effort to assist in carrying out the program implementation services and counseling guidance in schools

2) The BK teacher is expected to be able to prepare competent students and take chances in changes in the Industrial Revolution 4.0 era, especially in planning students' careers.

3) Students are expected to be able to have career planning, find information about the selection of majors and about work in the community.

4) For further researchers the results of this study are expected to be a reference for further research. Further researchers who are interested in career planning problems can use career information services because these services have been proven to improve student career planning.

\section{References}

[1] Suherman, Uman. (2009), Konseling Karir Sepanjang Rentang Kehidupan. Bandung: Sekolah PascaSarjana UPI.

[2] Atmaja, Twi. (2014), Upaya Meningkatkan Perencanaan Karir Siswa Melalui Bimbingan Karir dengan penggunaan Media Modul. Jakarta : Psikopedagogia.

[3] Karnawati, D. (2017). Revolusiindustri, 75\% Jenis Pekerjaanakan Hilang, https://ekbis.sindonews.com/read/1183599/34/revolusi-industri-75-jenis-pekerjaan-akanhilang-1488169341.

[4] Schwab, K. (2017), The Fourth Industrial Revolution. Jakarta: Crown Business Press.

[5] Kemenristek Dikti. (2018), Digitalisasi Ancam Ratusan Juta Pekerjaan, https://ekbis.sindonews.com/read/1357343/34/digitalisasi-ancam-ratusan-juta-pekerjaan1543109531diakses pada tanggal 28 Maret 2019 
[6] Prayitno dan Erman Amti.(2013), Dasar-Dasar Bimbingan dan Konseling. Jakarta: Rineka Cipta.

[7] Nurihsan, Ahmad Juntika. (2006), Bimbingan dan Konseling Dalam Berbagai Latar Kehidupan. Bandung: PT.RefikaAditama.

[8] Mulyadi. (2006), Bimbingan dan Konseling di Sekolah dan Madrasah. Jakarta: Prenadamedia Group.

[9] Arikunto, Suharsimi. (2006), Prosedur Penelitian. Jakarta: PT.Rineka Cipta.

[10] Dillard, Wulan Ayodya. (2013). Mau Kemana Setelah SMK. Jakarta: Esensi, Erlangga

[11] Adiputri dan Dwikurnaningsih. (2014), Pengaruh Layanan Informasi Karier Terhadap Kemampuan Perencanaan Karier Siswa Kelas XI Sma Negeri 2 Cepu. UKSW

[12] Anisa, Laelatul. (2015), Model Layanan Informasi Karir Dengan Teknik Field Trip Untuk Meningkatkan Perencanaan Karir Siswa Smk Di Kabupaten Demak. Universitas Muria Kudus. 